\title{
PENGARUH KEPEMILIKAN INSTITUSIONAL DAN PENGUNGKAPAN SUKARELA TERHADAP BIAYA HUTANG
}

(Studi pada Perusahaan Manufaktur Pengolahan Logam yang Terdaftar di Bursa Efek Indonesia)

\author{
Oleh : \\ Silviana Agustami \\ (Program Studi Akuntansi FPEB Universitas Pendidikan Akuntansi) \\ Anggun Cahyani Yunanda \\ (Program Studi Akuntansi FPEB Universitas Pendidikan Akuntansi)
}

\begin{abstract}
This research aims to find out about the effect of institutional ownership and voluntary disclosure of the interest expense on the companies manufacturing metal processing listed in Indonesia Stock Exchange. The samples used were as many as 10 metal processing manufacturing company for three years from 2010 to 2012 with a total of 30 samples by purposive sampling method. In this research, researchers used a documentary study conducted by collecting secondary data with web browsing. Voluntary disclosure is measured by scoring method on voluntary disclosure criteria that have been set. Data analysis was performed with the classical assumption and hypothesis testing with simple linear regression method. The test results show that institutional ownership is proven negative effect on the cost payable by $32 \%$ and voluntary disclosure does not have a negative effect on the cost payable.
\end{abstract}

Keywords: Institutional Ownership, Voluntary Disclosure, Cost Payable.

\section{Pendahuluan}

Persaingan antar perusahaan semakin ketat dan menuntut perusahaan untuk tetap bertahan dan lebih unggul dibanding perusahaan yang lain. Untuk itu, perusahaan harus selalu berinovasi dan berkembang. Maka, perusahaan membutuhkan manajemen yang handal dan dana yang tidak sedikit. Untuk mendapat tambahan dana, perusahaan dapat memperolehnya dari pinjaman, maupun menjual sahamnya. Banyak cara dilakukan sedemikian mungkin unuk menarik para investor atau kreditor agar mau memberikan pinjaman modal demi kelancaran bisnis suatu perusahaan. Di sisi lain para investor maupun kreditor terkadang ragu untuk menanamkan modalnya disuatu perusahaan karena sebab sebab tertentu.

Risiko suatu perusahaan dijadikan sebagai keputusan untuk pengambilan investasi maupun pinjaman kepada suatu perusahaan. Kreditor mengharapkan return yang akan didapatkan kelak sesuai dengan risiko yang diambil. Oleh sebab itu kreditor pun perlu menganalisis tentang perusahaan yang akan dipinjamkan modal. Kreditor harus mengetahui dan mempertimbangkan besar kecilnya risiko mengenai kondisi pasar yang akan diambil. Survei Norton Rose yang bertema Indonesia Inward Investment: An Industry Survey (2011: 16) menyatakan bahwa 
57\% responden dari pelaku industri di hampir seluruh dunia menyatakan bahwa negara Indonesia merupakan salah satu negara tujuan berinvestasi dengan risiko tinggi. Faktor lemahnya penegakan hukum, maraknya kasus korupsi hingga keterbatasan infrastruktur menjadi alasan mengapa Indonesia menjadi salah satu negara dengan High Risk Level.

Selain itu Survey Jetro juga mengungkapkan hasil dari survey yang menyatakan bahwa Indonesia termasuk dalam negara dengan tingkat risiko yang tinggi dibandingkan dengan negara lain. Risiko dari segi infrastruktur, biaya pekerja, hukum di indoneisa yang masih sangat lemah, maupun risiko politik yang menjadi alasan mengapa Indonesia termasuk High Risk Level. Berikut tabel berdasarkan hasil dari Survey Jetro:

Tabel 1.2

Risiko dan Masalah tiap Negara Berdasarkan Survey Jetro

\begin{tabular}{|c|c|c|c|c|c|c|}
\hline & $\begin{array}{c}\text { High level } \\
\text { offoreign } \\
\text { exchange } \\
\text { risk }\end{array}$ & $\begin{array}{c}\text { Inadequate } \\
\text { infrastructure }\end{array}$ & $\begin{array}{c}\text { Undeveloped } \\
\text { legal system } \\
\text { and problems } \\
\text { in application } \\
\text { of law }\end{array}$ & $\begin{array}{c}\text { High or } \\
\text { rising } \\
\text { labor } \\
\text { cost }\end{array}$ & $\begin{array}{c}\text { Labor } \\
\text { difficulties }\end{array}$ & $\begin{array}{c}\text { Political } \\
\text { Risk }\end{array}$ \\
\hline China & $12.3 \%$ & $11.6 \%$ & $45.1 \%$ & $49.5 \%$ & $34.1 \%$ & $64.6 \%$ \\
\hline Thailand & $10.4 \%$ & $10.5 \%$ & $6.5 \%$ & $30.1 \%$ & $12.7 \%$ & $15.3 \%$ \\
\hline Malaysia & $9.7 \%$ & $10.0 \%$ & $6.8 \%$ & $15.9 \%$ & $9.3 \%$ & $2.1 \%$ \\
\hline Indonesia & $12.4 \%$ & $36.4 \%$ & $27.2 \%$ & $21.0 \%$ & $22.1 \%$ & $18.5 \%$ \\
\hline Philippines & $8.8 \%$ & $28.6 \%$ & $15.6 \%$ & $7.3 \%$ & $8.8 \%$ & $14.4 \%$ \\
\hline Vietnam & $14.2 \%$ & $43.6 \%$ & $27.8 \%$ & $18.1 \%$ & $11.9 \%$ & $4.4 \%$ \\
\hline
\end{tabular}

Sumber : Survey Jetro 2013 (diolah kembali)

Persentase risiko dihitung tinggi jika melebihi 20\%. Indonesia mencapai $36 \%$ berisiko tinggi di infrastrukturnya, 27,2\% risiko di legal system dan hukum Indonesia yang masih sangat lemah. Belum juga masalah biaya pekerja yang mencapai $21 \%$ urutan ketiga setelah China dan Thailand. Dibandingkan dengan Malaysia, Indonesia memiliki tingkat risiko yang jauh lebih tinggi. Hal hal seperti ini yang membuat Indonesia tergolong dalam High Risk Jurisdiction.

Dengan demikian, artinya ketika suatu negara sudah diindikasikan sebagai High Risk Jurisdiction, maka biaya hutang (cost of debt) yang di tetapkan oleh kreditor pun akan besar pula. Madura (2006: 246) mengatakan bahwa "biaya utang lebih tinggi di beberapa negara berkembang dengan tingkat risiko tinggi dibandingkan dengan negara industri, terutama karena kondisi ekonomi”. Cost of debt (biaya utang) adalah tingkat pengembalian yang diinginkan kreditur saat memberikan pendanaan kepada perusahaan (Indah Masri dan Martani, 2012).

Dikutip dalam berita detikFinance pada Sabtu 18 Mei 2013, Menteri Perdagangan Gita Wirjawan mengatakan bahwa bunga kredit di Indonesia mencapai $10 \%$, sementara di Malaysia hanya 2\%. Dengan demikian sangat jelas 
bahwa Malaysia dengan tingkat risiko yang rendah akan mendapatkan tingkat bunga yang rendah pula, berbeda dengan Indonesia yang memiliki risiko investasi yang tinggi maka tingkat bunga yang didapat pun jauh lebih tinggi dibandingkan Malaysia.

Scott, et. al (2011: 431) mengatakan bahwa "If management accepts investments with high levels or risk or if it uses debt or preferred stock extensively, the firm's risk increase. Investor then require a higher rate of return, which causes a higher cost of capital to the company". Dapat disimpulkan bahwa jika manajemen menerima investasi dengan risiko yang tinggi dengan menggunakan hutang maupun saham preferen. Maka investor menuntut tingkat pengembalian yang tinggi, ini menyebabkan biaya modal menjadi lebih tinggi pula.

Dra. Sri Handaru Yuliati dalam bukunya Dasar Dasar Manajemen Keuangan Internasional (1997) menuliskan bahwa "biaya utang terutama ditentukan oleh tingkat bunga bebas risiko dan premi risiko. Tingkat bunga bebas risiko merupakan kompensasi karena kreditur mau menunda kegiatan konsumsinya. Sementara premi risiko merupakan penghargaan atas ketersediaan kreditur menanggung risiko tidak terbayarnya bunga dan pokok hutang."

Dengan adanya fenomena fenomena tersebut maka hal ini menjadi sebuah tugas besar suatu perusahaan di Indonesia untuk meyakinkan para kreditor bahwasanya perusahaan mereka jauh dari risiko investasi yang selama ini dijadikan bahan pertimbangan dari para kreditor. Oleh sebab itu perusahaan sering menerapkan sistem good corporate governance. Dengan sistem ini perusahaan berharap hal ini dapat memberikan reaksi positif bagi para investor maupun kreditor. Perusahaan mengharapkan mendapatkan pinjaman modal dengan biaya hutang (cost of debt) yang serendah mungkin.

Gunarsih (2003) dalam Yulisa Rebecca (2011) berpendapat bahwa isu corporate governance muncul karena adanya pemisahan antara kepemilikan dan pengelolaan perusahaan. Pemisahaan antara fungsi kepemilikan dan pengelolaan perusahaan menimbulkan kemungkinan terjadinya agency problem yang dapat menyebabkan agency conflict, yaitu konflik yang timbul sebagai akibat keinginan manajemen (agent) untuk melakukan tindakan yang sesuai dengan kepentingannya yang dapat mengorbankan kepentingan pemegang saham.

Penelitian Asbaugh et. al (2004) dalam Juniarti (2009) membuktikan bahwa perusahaan dengan good corporate governance yang kuat ternyata memiliki peringkat kredit (credit ratings) yang lebih tinggi dibandingkan perusahaan dengan good corporate governance yang lemah. Dengan sistem good corporate governance yang kuat dapat membuat para investor dan kreditor percaya kepada perusahaan kita, karena penerapan good corporate governance yang kuat membuktikan bahwa terdapat pengelolaan manajemen yang baik sehingga risiko yang diterima oleh para investor dan kreditor pun semakin kecil. Itulah sebabnya bahwa perusahaan dengan good corporate governance yang kuat akan mendapatkan keuntungan berupa biaya hutang (cost of debt) yang rendah.

Kepemilikan institusional merupakan bagian dari prinsip good corporate governance. Perusahaan akan melakukan pengawasan yang ketat terhadap kinerja maupun pengelolaan suatu menejemen perusahaan apabila kepemilikan institusional diluar perusahaan jumlahnya cukup signifikan. 
Jensen (1993) mengenai teori keagenan dalam Yulisa Rebecca (2011) berpendapat bahwa investor institusional, yang juga berperan sebagai fidusiari, memiliki insentif yang lebih besar untuk memantau manajemen dan kebijakan perusahaan. Pemantauan yang efektif dari investor institusional dapat mengurangi perilaku oportunistik manajemen yang mengarah pada berkurangnya agency cost dan biaya ekuitas yang lebih rendah.

Cornett et. al (2006) dalam Juniarti (2009) menemukan adanya bukti yang menyatakan bahwa tindakan pengawasan yang dilakukan oleh sebuah perusahaan dan pihak investor institusional dapat membatasi perilaku manajemen. Tindak pengawasan yang ketat dapat menurunkan risiko perusahaan yang tidak diinginkan, dengan menurunnya risiko suatu perusahaan maka tingkat bunga yang diberikan kreditor pun akan lebih kecil.

Pengungkapan (disclosure) merupakan salah satu bentuk keterbukaan atau transparansi suatu perusahaan. Transparansi suatu informasi keuangan suatu perusahaan adalah bentuk pertanggungjawaban perusahaan terhadap para investor maupun kreditor, dan hal ini akan menjadi suatu bahan pertimbangan para investor maupun kreditor untuk memutuskan apakah akan menanamkan atau meminjamkan modalnya pada perusahaan tersebut. Pengungkapan diharapkan mampu untuk membantu kreditur dalam memahami keadaan suatu perusahaan.

Sabrina (2007) berpendapat bahwa Investor dan kreditur, ketika akan meminjamkan sejumlah uang kepada perusahaan, mencoba untuk memperkirakan default risk perusahaan berdasarkan semua informasi yang tersedia tersebut. Demikian juga halnya dengan penjamin (underwriters) akan memasukkan perkiraan default risk dalam bayaran (fees) mereka. Salah satu faktor yang mungkin masuk dalam perhitungan default risk mereka adalah bahwa perusahaan menyembunyikan unfavorable information, dimana unfavorable information tersebut akan mengakibatkan naiknya default risk perusahaan.

Pengungkapan dikategorikan menjadi dua jenis yaitu pengungkapan yang bersifat wajib (mandatory), yaitu pengungkapan yang wajib dilakukan oleh perusahaan yang didasarkan pada standar atau peraturan tertentu. Pengungkapan yang bersifat sukarela (voluntary), yaitu pengungkapan informasi yang tidak diharuskan oleh badan penyelenggara pasar modal.

Perusahaan yang melakukan pengungkapan sukarela (voluntary disclosure) merupakan perusahaan dengan tingkat transparansi yang tinggi. Transparansi suatu perusahaan pun dinilai akan mengurangi risiko. Maka, biaya hutang (cost of debt) yang diterima pun semakin kecil. Sengupta (1998) dalam R. Lanny Wulansari (2004) memberikan bukti bahwa perusahaan yang memiliki rating disclosure quality yang tinggi dari para analis keuangan, akan menikmati interest cost of issuing debt yang lebih rendah. Ia menyimpulkan bahwa persahaan yang memiliki cost of debt yang rendah, dinilai daari tingkat kualitas disclosure yang tinggi.

Sebagai dasar pengambilan keputusan para investor maupun kreditor, informasi yang disajikan harus dapat dipahami, di percaya, relavan, dan transparan. Karena sebagaimana yang kita ketahui bahwa kegiatan investasi merupakan suatu kegiatan yang mengandung risiko. Oleh sebab itu investor dan kreditor sebisa mungkin mengurangi risiko yang ada dengan memilih perusahaan yang trebuka dan transparan. 
Perusahaan yang dipakai penelitian ini adalah perusahaan perusahaan di bidang manufaktur yang terdaftar di Bursa Efek Indonesia. Alasan penulis menggunakan data dari perusahaan manufaktur dikarenakan perusahaan manufaktur merupakan perusahaan yang memproduksi barang tiap harinya. Untuk itu perusahaan membutuhkan biaya yang cukup tinggi, dan biaya yang diperoleh dapat berupa utang dan sebagainya.

The World Bank, yang bertema Revitalisasi Pertumbuhan di Sektor Manufaktur Indonesia mengatakan bahwa setelah pernah mendapat predikat bintang, sejak krisis Asia tahun 1997, reputasi sektor manufaktur Indonesia meredup karena penurunan kinerja dibandingkan sektor manufaktur di kawasan regional maupun antara sektor-sektor perekonomian lainnya. Menurut berita (finance.detik.com) pada tahun 2011, Menteri Perindustrian Hidayat tidak menyangkal adanya gejala deindustrialisasi mengingat semenjak tahun 2005 pertumbuhan sektor manufaktur berada dibawah rata rata. Tercatat pertumbuhan hanya sebesar 2,3\% jauh dari yang di targetkan sekitar 5\%. Menurut anggota komisi VI DPR Sukur Nababan, industri manufaktur terpuruk akibat buruknya infrastruktur, banyaknya pungutan liar, lemahnya penegakan hukum dan peraturan yang kurang mendukung sehingga menyebabkan ekonomi biaya tinggi. Hal ini dapat menjadi risiko bagi para kreditur, dan berdampak pada suku bunga yang diterima akan tinggi pula. Menurut Keluarga Mahasiswa ITB (km.itb.ac.id), salah satu penyebab di balik deindustrialisasi di Indonesia adalah rendahnya dukungan perbankan. Pada tahun 2008, industri manufaktur hanya memperoleh $15 \%$ kredit perbankan. Salah satunya karena banyak industri manufaktur yang dianggap bermasalah.

Badan Pusat Statistik dalam keterangan pers di Jakarta (bisnis.liputan6.com) mengatakan bahwa industry manufaktur yang mengalami penurunan paling tinggi dialami oleh logam dasar sebesar 8,48 \%, diikuti oleh tekstil sebesar 8,32 \%, furniture 6,6 \%, kertas sebesar 4,37 \%, dan pengolahan lainnya sebesar 3,49\%. Disaat sektor lain meningkat, sektor manufaktur justru mengalami penurunan terutama di subsektor logam. Berikut adalah grafik The World Bank, Revitalisasi Pertumbuhan di Sektor Manufaktur Indonesia.

Grafik 1.1

Penurunan Subsektor Manufaktur Indonesia 


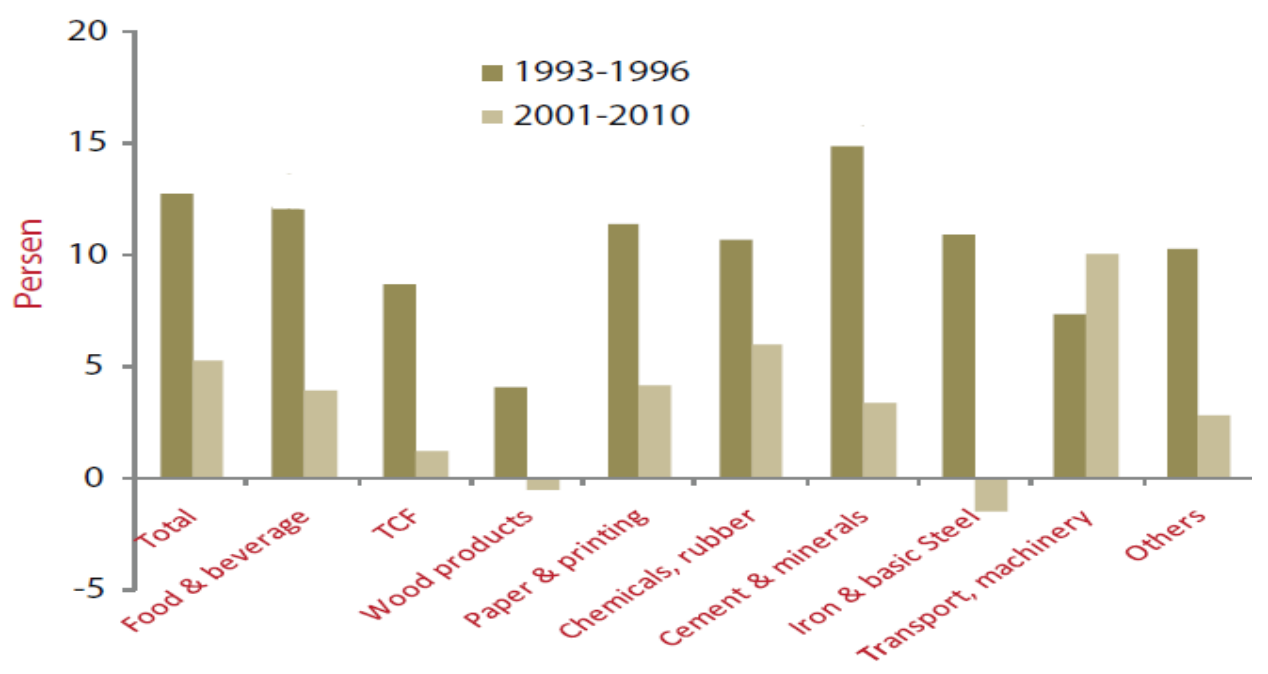

Sumber : The World Bank

Dari grafik diatas menggambarkan bahwa penurunan dari logam dan baja sangat signifikan dibandingkan dengan subsektor yang lainnya. Dari fenomena fenomena diatas makan peneliti akan meneliti perusahaan manufaktur subsektor logam sebagai subjek penelitian ini.

Dari beberapa penelitian penelitian sebelumnya seperti Yulisa Rebecca (2011) meneliti tentang "Pengaruh corporate governance index, kepemilikan keluarga, dan kepemilikan institusional terhadap biaya ekuitas dan biaya hutang". Dari penelitian ini Rebecca menyimpulkan bahwa kepemilikan institusional tidak memiliki pengaruh signifikan terhadap biaya ekuitas namun terbukti berpengaruh signifikan negatif terhadap biaya utang. Indah Masri dan Dwi Martani (2012) meneliti tentang "Pengaruh tax avoidance terhadap cost of debt" dan menarik kesimpulan bahwa tax avoidance terbukti menyebabkan biaya hutang menjadi lebih besar. Retno dan Ida Bagus (2011) juga meneliti tentang "analysis of the impact of family ownership on a company's cost of debt" dan menyimpulkan bahwa proporsi kepemilikan keluarga memiliki hubungan yang signifikan dengan biaya utang. Begitu pula dengan Aldamen (2010) yang dalam penelitiannya "corporate governance, risk assessment and cost of debt" menyimpulkan bahwa corporate governance berdampak negatifpada default risiko dan dimensi informasi risiko dan ketiga faktor ini digabungkan untuk mengurangi biaya utang.

Disini peneliti menggunakan kepemilikan institusional dan pengungkapan sukarela (voluntary disclosure) sebagi variabel dependen yang dapat dilihat dari beberapa penelitian sebelumnya bahwa hasil penelitian mengenai kepemilikan institusional dan pengungkapan sukarela terhadap biaya hutang masih terdapat hasil yang tidak konsisten maka peneliti tertarik untuk meneliti ulang. Perusahaan yang diteliti adalah perusahaan manufaktur subsektor logam dan sejenisnya yang terdaftar di bursa efek indonesia dengan kriteria tertentu dengan periode tahun $2010-2012$.

\section{Kajian Pustaka}

Risiko suatu perusahaan dijadikan sebagai keputusan untuk pengambilan investasi maupun pinjaman kepada suatu perusahaan. Tingginya tingkat bunga atas pinjaman jangka panjang dikaitkan dengan risiko pengembalian (Lukman Syamsuddin, 2007: 208). Madura (2006: 246) mengatakan bahwa biaya utang 
lebih tinggi di beberapa Negara berkembang dengan tingkat risiko tinggi dibandingkan dengan negara industri, terutama karena kondisi ekonomi.

Seperti yang kita ketahui bahwa kepemilikan institusional memiliki peran penting dalam mengawasi jalannya bisnis suatu perusahaan. Jensen dan Meckling (1976) dalam Wien (2010) menyatakan bahwa kepemilikan institusional memiliki peranan yang sangat penting dalam meminimalisasi konflik keagenan yang terjadi antara manajer dan pemegang saham. Peran investor institusional dianggap mampu untuk mengawasi dari setiap keputusan yang diambil oleh manajer perusahaan, hal ini dilakukan guna menjamin keuntungan para pemegang saham agar modal yang mereka berikan bisa dipergunakan dan di atur sebaik mungkin.

Jensen (1993) serta Shleifer dan Vishny (1997) dalam Yulisa Rebecca (2011) berpendapat bahwa investor institusional, yang juga berperan sebagai fidusiari, memiliki insentif yang lebih besar untuk memantau manajemen dan kebijakan perusahaan. Pemantauan yang efektif dari investor institusional dapat mengurangi perilaku oportunistik manajemen yang mengarah pada berkurangnya agency cost dan biaya ekuitas yang lebih rendah.

Cornett et. Al (2006) dalam Juniarti (2009) menemukan adanya bukti yang menyatakan bahwa tindakan pengawasan yang dilakukan oleh sebuah perusahaan dan pihak investor institusional dapat membatasi perilaku manajemen. Tindak pengawasan yang ketat dapat menurunkan risiko perusahaan yang tidak diinginkan, dengan menurunnya risiko suatu perusahaan maka tingkat bunga yang diberikan kreditor pun akan lebih kecil.

Penelitian yang dilakukan oleh Bhojraj dan Sengupta (2003) yang dikutip oleh Yulisa Rebecca (2011) menemukan bahwa kepemilikan institusional dapat mengurangi biaya utang perusahaan. Hal ini dikarenakan adanya monitoring yang efektif oleh pihak institusional dapat mendorong manajemen untuk meningkatkan kinerja perusahaan. Meningkatnya kinerja perusahaaan membuat risiko perusahaan menjadi lebih kecil sehingga return yang diinginkan oleh kreditur pun menjadi lebih rendah.

Perusahaan dengan sistem pengawasan yang bagus dan tepat akan meminimalisir terjadinya kecurangan yang dilakukan oleh oknum oknum tertentu, hal ini dapat mengurangi risiko suatu perusahaan. Dengan pengawasan dari pihak institusional yang tinggi maka risiko suatu perusahaan akan kecurangan pun berkurang dan dengan tingkat risiko yang lebih rendah maka biaya hutang yang akan diterima perusahaan pun akan lebih rendah.

Seperti yang sudah dibahas sebelumnya bahwa dari beberapa sumber mengatakan bahwa tingkat risiko suatu perusahaan sangat berpengaruh terhadap besar kecilnya biaya hutang yang didapat. Semakin tinggi suatu risiko maka kreditur akan mengharapkan return yang tinggi pula. Return yang dimaksud adalah berupa bunga.

Sabrina (2007) berpendapat bahwa Investor dan institusi keuangan, ketika akan meminjamkan sejumlah uang kepada perusahaan, mencoba untuk memperkirakan default risk perusahaan berdasarkan semua informasi yang tersedia tersebut. Demikian juga halnya dengan penjamin (underwriters) akan memasukkan perkiraan default risk dalam bayaran (fees) mereka. Salah satu faktor yang mungkin masuk dalam perhitungan default risk mereka adalah bahwa perusahaan menyembunyikan unfavorable information, dimana unfavorable information tersebut akan mengakibatkan naiknya default risk perusahaan. 
Pengungkapan bagi suatu perusahaan diharapkan mampu untuk membatu para investor maupun kreditor dalam pengambilan keputusan. Baik itu membeli saham, menjualnya, mempertahankan, maupun dalam pertimbangan return yang ingin didapat.

Sengupta (1998) dalam R.Lanny Wulansari (2004) memberikan bukti bahwa perusahaan yang memiliki rating disclosure quality yang tinggi dari para analis keuangan, akan menikmati interest cost of issuing debt yang lebih rendah. Ia menyimpulkan bahwa persahaan yang memiliki cost of debt yang rendah, dinilai daari tingkat kualitas disclosure yang tinggi.

Menurut Ainun Na'im dan Fu'ad Rakhman (2000) dalam Sabrina (2007), salah satu cara bagi manajer untuk meningkatkan kredibilitas perusahaan adalah melalui pengungkapan sukarela secara lebih luas. Pengungkapan sukarela dapat membantu investor dalam memahami strategi bisnis manajemen. Perusahaan dapat lebih menarik perhatian lebih banyak analis, menungkatkan akurasi ekspektasi pasar dan menurunkan ketidaksimetrisan informasi pasar.

Perusahaan yang melakukan pengungkapan sukarela (voluntary disclosure) dinilai sebagai perusahaan dengan tingkat transparansi yang tinggi. Semakin terbuka suatu perusahaan mengenai informasi keuangan perusahaan tersebut maka ada rasa percaya dari pihak kreditor untuk meminjamkan modalnya kepada perusahaan tersebut karena ada rasa tenang karena tidak ada manipulasi oleh suatu perusahaan. Transparansi suatu perusahaan pun dinilai akan mengurangi risiko. Maka, biaya hutang (cost of debt) yang diterima pun semakin kecil.

\section{Metode Penelitian}

Dalam penyusunan skripsi ini, metode penelitian yang digunakan penulis adalah metode kausalitas. Metode kausalitas menurut Kuncoro (dalam Dede Andri, 2012:71) adalah 'selain mengukur kekuatan hubungan antara dua variabel atau lebih juga menunjukkan arah hubungan antara variabel independen dengan variabel dependen.

Dalam penelitian, data memiliki kedudukan yang sangat penting karena data merupakan penggambaran variabel yang diteliti dan berfungsi sebagai alat pembuktian hipotesis yang akan menjadi kesimpulan penelitian. Kesimpulan penelitian yang berupa jawaban atau pemecahan masalah penelitian dibuat berdasarkan hasil proses pengujian data yang meliputi pemilihan, pengumpulan dan analisis data.

Asumsi-asumsi yang harus dipenuhi dalam menyusun regresi linier agar hasilnya tidak bias, maka harus dilakukan uji asumsi klasik di bawah ini :

1. Uji Normalitas

Uji normalitas bertujuan untuk menguji apakah dalam model regresi, variabel pengganggu atau residual memiliki distribusi normal. Dalam uji normalitas ini ada 2 cara untuk mendeteksi apakah residual berdistribusi normal atau tidak, yaitu dengan analisis grafik dan uji statistik (Ghozali, 2009). Alat uji yang digunakan adalah dengan analisis grafik histogram dan grafik normal probability plot dan uji statistik dengan Kolmogorov-Smirnov (1-sample K-S).

Dasar pengambilan keputusan dengan analisis grafik normal probability plot adalah (Ghozali, 2009): (1) Jika data menyebar di sekitar garis diagonal dan mengikuti arah garis diagonal atau grafik histogramnya menunjukan pola 
distribusi normal, makamodel regresi memenuhi syarat normalitas; (2) Jika data menyebar jauh dari diagonal dan/atau tidak mengikuti arah garis diagonal atau grafik histogram tidak menunjukan pola distribusi normal,maka model regresi tidak memenuhi asumsi normalitas.

Dasar pengambilan keputusan uji statistik dengan Kolmogorov-Smirmov Z(I-Sample K-S) adalah (Ghozali, 2009):( (1) Apabila nilai Asymp. Sig (2-tailed) kurang dari 0,05 , maka $\mathrm{H} 0$ ditolak. Hal iniberarti ada data residual terdistribusi tidak normal; (2) Apabila nilai Asymp. Sig (2-tailed) lebih besar dari 0,05 maka H0 diterima.Hal ini berarti data residual terdistribusi normal.

2. Uji Linearitas

Salah satu asumsi penting lain pada sebuah model regresi adalah asumsi linieritas. "Maksudnya apakah garis regresi antara X dan Y membentuk garis linear atau tidak. Kalau tidak linear maka analisis regresi tidak dapat dilanjutkan" (Sugiyono, 2011:265).

3. Uji Heteroskedastisitas

Menurut Ghozali (2009) "UjiHeteroskedastisitas bertuuan untuk menguji apakah dalam model regresi terjadi ketidaksamaan varian dari residual satu pengamatan ke pengamatan lain". Cara memprediksi ada tidaknya heteroskedastisitas pada suatu model dapat dilihat dengan pola gambar scatterplot, regresi yang tidak heteroskedastisitas jika: (1) Titik-titik data menyebar diatas dan dibawah atau disekitar angka 0; (2) Titik-titik data tidak mengumpul hanya diatas atau dibawah saja; (3) Penyebaran titik-titik data tidak boleh membentuk pola bergelombang, melebar kemudian menyempit dan melebar sekali; (4) Penyebaran titik-titik data tidak berpola.

4. Uji Autokorelasi

Menurut Ghozali (2009) "Uji autokorelasi bertujuan untuk menguji apakah dalam model regresi linier ada korlasi antara kesalahan penganggu pada periode $t$ dengan kesalahan pada periode t-1 sebelumnya". Untuk mendeteksi autokorelasi menggunakan pengujian statistik Durbin Watson (DW) hasil perhitungan dari SPSS. Kriteria yang dipakai dalam pengujian ini adalah

1. Jika nilai DW dibawah 0 sampai 1,5 berarti ada autokorelasi positif

2. Jika nilai DW diantara 1,5 sampai 2,5 berarti tidak ada autokorelasi

3. Jika nilai DW diantara 2,5 sampai 4 berarti ada autokorelasi negative

Hipotesis dapat diartikan sebagai suatu jawaban yang bersifat sementara terhadap permasalahan penelitian, sampai terbukti melalui data yang terkumpul (Suharsimi Arikunto, 2006:71).

Uji hipotesis dimaksudkan untuk melihat bagaimana hubungan kedua variabel, dimana hipotesis nol (Ho) umumnya diformulasikan untuk ditolak, sedangkan hipotesis alternatif $\left(\mathrm{H}_{1}\right)$ merupakan hipotesis yang diajukan dalam penelitian ini. Hipotesis dalam penelitian ini akan diuji dengan menggunakan analisis regresi linier sederhana.

a. Analisis Regresi Linier Sederhana

Regresi linier sederhana didasarkan pada hubungan fungsional ataupun kausal satu variabel independen dengan satu variabel dependen. Untuk menguji hipotesis yang diajukan dalam penelitian ini digunakan analisis regresi linier sederhana. Dengan rumus sebagai berikut :

$$
\mathrm{Y}=\mathrm{a} \pm \mathrm{bX}
$$


Dimana :

$\mathrm{Y}=$ subjek dalam variabel dependen yang diprediksikan.

$\mathrm{a}=$ harga $\mathrm{Y}$ bila $\mathrm{X}=0$ (konstan)

$\mathrm{b}=$ angka arah koefisien regresi yang menunjukkan angka peningkatan ataupun penurunan variabel dependen yang didasarkan pada variabel independen. Bila $\mathrm{b}(+)$ maka naik dan bila $\mathrm{b}(-)$ maka terjadi penurunan.

$\mathrm{x}=$ subjek variabel independen yang mempunyai nilai tertentu.

Dalam penelitian ini, nilai-nilai dalam persamaan tersebut dicari melalui program SPSS.

b. Menghitung Koefisien Determinasi

Setelah diketahui nilai koefisien korelasi (r) yang memperlihatkan derajat atau kekuatan korelasi antara variabel maka akan dihitung koefisien determinasi $\left(\mathrm{k}_{\mathrm{d}}\right)$ yang dapat memperlihatkan berapa persen variasi variabel $\mathrm{X}$ akan mempengaruhi variabel $\mathrm{Y}$ dengan rumus:

Keterangan:

$$
\mathrm{K}_{\mathrm{d}}=\mathrm{r}^{2} \mathrm{x} 100 \%
$$

$\mathrm{K}_{\mathrm{d}=}$ Koefisien determinasi

$\mathrm{r}=$ nilai koefisien korelasi

(Sudjana, 2004: 246)

nilai $\mathrm{K}_{\mathrm{d}}$ berada antara 0 sampai $1\left(0<=\mathrm{K}_{\mathrm{d}}<=1\right)$

- jika nilai $\mathrm{K}_{\mathrm{d}}=0$ berarti tidak ada pengaruh variabel $\mathrm{X}$ terhadap variabel $\mathrm{Y}$.

- jika nilai $\mathrm{K}_{\mathrm{d}}=1$ berarti variasi (naik turunnya) variabel dependen $\mathrm{Y}$ adalah $100 \%$ dipengaruhi oleh variabel independen (variabel X).

- jika nilai $K_{d}$ berada antara 0 sampai $1\left(0<=K_{d}<=1\right)$ maka besarnya pengaruh variabel independen adalah sesuai dengan nilai $K_{d}$ itu sendiri dan selebihnya berasal dari faktor-faktor yang lain.

\title{
Hasil dan Pembahasan
}

Analisis Regresi Linier Sederhana Kepemilikan Institusional dengan Biaya Hutang

\author{
Tabel Koefisien Regresi \\ (Periode 2010-2012)
}




\section{Coefficients}

\begin{tabular}{|ll|r|r|r|r|r|}
\hline \multirow{2}{*}{ Model } & \multicolumn{2}{|c|}{$\begin{array}{c}\text { Unstandardized } \\
\text { Coefficients }\end{array}$} & \multicolumn{2}{c|}{$\begin{array}{c}\text { Standardized } \\
\text { Coefficients }\end{array}$} & \\
\cline { 2 - 5 } & & \multicolumn{1}{c|}{$\mathrm{B}$} & Std. Error & \multicolumn{1}{c|}{ Beta } & \multicolumn{1}{c|}{$\mathrm{t}$} & \multicolumn{1}{c|}{ Sig. } \\
\hline 1 & (Constant) & .150 & .024 & & 6.343 & .000 \\
& Kepemilikan & -.249 & .068 & -.567 & -3.643 & .001 \\
\hline
\end{tabular}

a. Dependent Variable: Cost of Debt $(\mathrm{Y})$

Sumber: Data yang telah diolah dengan SPSS.

$$
\mathrm{Y}=\mathrm{a}+\mathrm{bX}
$$

Dimana : $\quad \mathrm{Y} \quad=$ Biaya Hutang

a $\quad$ = Harga konstan

$\mathrm{X} \quad=$ Kepemilikan Institusional

$\mathrm{b} \quad=$ Koefisien Regresi

Dari hasil pengolahan SPSS di atas didapat nilai $a=0,150$ dan nilai $b=-$ 0,249 . Dengan demikian diperoleh persamaan regresi linier sederhana sebagai berikut:

$$
\mathrm{Y}=0,150-0,249 \mathrm{X}
$$

Persamaan di atas dapat diartikan sebagai berikut:

$\mathrm{a}=0,150 \quad$ : artinya jika Kepemilikan Institusional $(\mathrm{X})$ bernilai nol (0), maka Biaya Hutang (Y) akan bernilai 0,150

$\mathrm{b}=-0,249$ : artinya jika Kepemilikan Institusional $(\mathrm{X})$ meningkat sebesar satu satuan, maka Biaya Hutang (Y) akan menurun sebesar 0,249 satuan.

Perumusan hipotesis untuk menguji apakah terdapat pengaruh yang signifikan atau tidak antara kedua variabel adalah sebagai berikut:

$\mathrm{H}_{0}: \mathrm{b}_{1}>0$, artinya Kepemilikan Institusional tidak berpengaruh negatif terhadap Biaya Hutang.

$\mathrm{H}_{1}: \mathrm{b}_{1}<0$, artinya Kepemilikan Institusional berpengaruh negatif terhadap Biaya Hutang.

Berdasarkan Tabel 4.11 didapat nilai t sebesar -3,643 dengan signifikansi sebesar 0,001. Karena dari hasil penelitian diperoleh nilai koefisien regresi sebesar -0,294 yang berarti lebih kecil dari nol $(b<0)$, maka diputuskan untuk menerima $\mathrm{H}_{1}$ sehingga $\mathrm{H}_{0}$ ditolak $\mathrm{Hal}$ ini menunjukkan Kepemilikan Institusional berpengaruh negatif terhadap Biaya Hutang.

\section{Analisis Koefisien Determinasi}

Setelah didapat nilai koefisien korelasi, kemudian dilakukan perhitungan persentase pengaruh Kepemilikan Institusional terhadap Biaya Hutang digunakan rumus Koefisien Determinasi $(\mathrm{KD})$ sebagai berikut:

Dimana :

$$
\mathrm{KD}=\left(\mathrm{r}_{\mathrm{xy}}\right)^{2} \times 100 \%
$$

$\mathrm{KD} \quad=$ koefisien determinasi

$\left(\mathrm{r}_{\mathrm{xy}}\right)^{2}=$ koefisien korelasi 


\begin{tabular}{|l|r|r|r|r|r|}
\multicolumn{7}{|c}{ Model Summarb } \\
\hline Model & $\mathrm{R}$ & R Square & $\begin{array}{c}\text { Adjusted } \\
\text { R Square }\end{array}$ & $\begin{array}{r}\text { Std. Error of } \\
\text { the Estimate }\end{array}$ & $\begin{array}{c}\text { Durbin- } \\
\text { Watson }\end{array}$ \\
\hline 1 & $.567^{\mathrm{a}}$ & .322 & .297 & .03858 & 2.051 \\
\hline
\end{tabular}

a. Predictors: (Constant), Kepemilikan Institusional (X1)

b. Dependent Variable: Cost of Debt $(Y)$

$$
\begin{aligned}
\mathrm{KD} & =\mathrm{r}_{\mathrm{yx}}{ }^{2} \times 100 \% \\
& =(0,567)^{2} \times 100 \% \\
& =32,2 \%
\end{aligned}
$$

Dari analisis diatas dapat dilihat bahwa Kepemilikan Institusional memiliki pengaruh terhadap Biaya Hutang sebesar 32,2\%, sedangkan sisanya sebesar $67,8 \%$ dipengaruhi oleh faktor lain yang tidak diamati.

a. Analisis Regresi Linier Sederhana Pengungkapan Sukarela dengan Biaya Hutang

\section{Tabel Koefisien Regresi

\begin{tabular}{|c|c|c|c|c|c|c|}
\hline \multirow{2}{*}{\multicolumn{2}{|c|}{ Model }} & \multicolumn{2}{|c|}{$\begin{array}{l}\text { Unstandardized } \\
\text { Coefficients }\end{array}$} & \multirow{2}{*}{$\begin{array}{c}\text { Standardized } \\
\text { Coefficients } \\
\text { Beta } \\
\end{array}$} & \multirow[b]{2}{*}{$t$} & \multirow[b]{2}{*}{ Sig. } \\
\hline & & $B$ & Std. Error & & & \\
\hline & (Constant) & .720 & .097 & & 7.443 & .000 \\
\hline & Voluntary Disclosure (X2) & .268 & .062 & .632 & 4.315 & .000 \\
\hline
\end{tabular} \\ (Periode 2010-2012)}

Coefficients

a. Dependent Variable: Cost of Debt $(Y)$

Sumber: Data yang telah diolah dengan SPSS

Dimana : $\quad \mathrm{Y} \quad=$ Biaya Hutang

$$
\mathrm{Y}=\mathrm{a}+\mathrm{bX}
$$

a $\quad$ = Harga konstan

$\mathrm{X}=$ Pengungkapan Sukarela

$\mathrm{b} \quad=$ Koefisien Regresi

Dari hasil pengolahan SPSS di atas didapat nilai $\mathrm{a}=0,720$ dan nilai $\mathrm{b}=$ 0,268. Dengan demikian diperoleh persamaan regresi linier sederhana sebagai berikut:

$$
\mathrm{Y}=0,720+0,268 \mathrm{X}
$$

Persamaan di atas dapat diartikan sebagai berikut:

$\mathrm{a}=0,720$ : artinya jika Pengungkapan Sukarela (X) bernilai nol (0), maka Biaya Hutang (Y) akan bernilai 0,720

$\mathrm{b}=0,268$ : artinya jika Pengungkapan Sukarela $(\mathrm{X})$ meningkat sebesar satu satuan, maka Biaya Hutang (Y) akan meningkat sebesar 0,268 satuan.

Perumusan hipotesis untuk menguji apakah terdapat pengaruh yang signifikan atau tidak antara kedua variabel adalah sebagai berikut:

$\mathrm{H}_{0}: \mathrm{b}_{1}>0$, artinya Pengungkapan Sukarela tidak berpengaruh negatif terhadap Biaya Hutang. 
$\mathrm{H}_{1}: \mathrm{b}_{1}<0$, artinya Pengungkapan Sukarela berpengaruh negatif terhadap Biaya Hutang.

Berdasarkan Tabel 4.15 didapat nilai t sebesar 4,315 dengan signifikansi sebesar 0,000. Karena dari hasil penelitian diperoleh nilai koefisien regresi sebesar 0,268 yang berarti lebih besar dari nol $(b<0)$, maka diputuskan untuk menerima $\mathrm{H}_{0}$ sehingga $\mathrm{H}_{1}$ ditolak. Hal ini menunjukkan Pengungkapan Sukarela tidak berpengaruh negatif terhadap Biaya Hutang.

Kepemilikan institusional adalah persentase kepemilikan yang dimiliki oleh sebuah institusi atau lembaga keuangan maupun pemerintah di suatu perusahaan. Penelitian ini bertujuan untuk mengetahui apakah kepemilikan institusional berpengaruh negatif terhadap biaya bunga pada 10perusahaan manufaktur logam pada tahun 2010 sampai dengan tahun 2012. Besar kepemilikan institusional pada perusahaan dan tahun tersebut persentasenya bermacam macam dari setiap perusahaannya, hanya saja dari tahun 2010 sampai dengan tahun 2012 perusahaan yang terjadi perubahan pada persentase kepemilikan institusionalnya hanya berjumlah 1 perusahaan saja. Perusahaan lainnya memiliki persentase kepemilikan institusional yang sama di setiap tahunnya.

Hasil pengujian mengatakan bahwa kepemilikan institusional berpengaruh negatif terhadap biaya hutang. Nilai t sebesar -3,643 dengan signifikansi sebesar 0,001. Dikarenakan nilai signifikansi lebih kecil dari 0,05 $(0,001<0,05)$ maka $\mathrm{H}_{0}$ ditolak dan $\mathrm{H}_{1}$ diterima. Hal ini menunjukkan Kepemilikan Institusional berpengaruh negatif terhadap Biaya Hutang. Penelitian ini mendukung teori agensi yang mengatakan bahwa kepemilikan institusional dapat mengurangi konflik keagenan dikarenakan kepemilikan institusional berperan penting dalam mengawasi jalannya suatu perusahaan dengan demikian perusahaan dianggap berisiko rendah dan biaya bunga yang diapat pun akan semakin rendah pula. Hasil penelitian ini juga mendukung hasil penelitian Juniarti dan Agnes (2009) juga penelitian Yulisa (2011) yang mengatakan bahwa kepemilikan institusional berpengaruh negatif terhadap biaya hutang.

Pengungkapan Sukarela adalah suatu pengungkapan laporan keuangan yang dilakukan secara sukarela diluar dari pengungkapan yang diwajibkan. Pada 10 perusahaan manufaktur logam yang diteliti dari tahun 2010 sampai dengan tahun 2012, item pengungkapan yang dilakukan oleh perusahaan perusahaan tersebut relatif rendah dan tidak ada yang mencapai total maksimum pengungkapan sukarela yaitu sebesar 42 item. Jumlahnya tiap perusahaan pun bermacam macam dan berubah ubah setiap tahunnya.

Hasil pengujian mengatakan bahwa pengungkapan sukarela tidak berpengauh negatif terhadap biaya hutang. Nilai $\mathrm{t}$ sebesar 4,315, hal ini menunjukkan pengungkapan sukarela tidak berpengaruh negatif terhadap biaya hutang. Kreditur seringkali tidak menggunakan informasi yang tersedia dalam pemberian pinjaman seperti pengungkapan sukarela. Kreditur lebih menilai kepada track record perusahaan dalam meminjam suatu hutang, apakah dinilai baik atau buruk. Hal tersebut akan lebih memberikan penilaian suatu kreditur terhadap perusahaan dibandingkan hanya melihat pengungkapan yang belum tentu bernilai positif pada penilaian kreditur. Perusahaan dengan sejarah kredit yang baik maka akan mendapatkan penilaian positif bagi kreditur. 
Hasil penelitian ini tidak mendukung teori agency pada perusahaan dan tahun yang telah diteliti. Juga berbeda hasil penelitian dengan yang dilakukan oleh Lanny (2004) tetapi peneltian ini mendukung penelitian Juniarti dan Agnes (2009) juga penelitian Nancy (2010) yang mengatakan bahwa pengungkapan sukarela tidak terbukti berpengaruh negatif terhadap biaya hutang.

\section{Simpulan}

Dari hasil analisa dan pengolahan data yang telah dilakukan pada bab sebelumnya, maka dapat disimpulkan sebagai berikut :

1. Kepemilikan Institusional berpengaruh negatif terhadap Biaya Hutang. Artinya bahwa semakin besar persentase kepemilikan institusional dalam suatu perusahaan maka biaya hutang yang diterima pun akan semakin rendah. Hal ini dikarenakan kepemilikan institusional berperan aktif dalam mengawasi jalannya suatu usaha sehingga risiko atas suatu perusahaan semakin kecil dan biaya hutang yang diterima pun akan semakin kesil. Hasil dari penelitian ini mendukung teori agensi. Dari hasil penelitian didapatkan bahwa kepemilikan institusional berpengaruh sebesar 32\% terhadap biaya bunga dan $68 \%$ lainnya dipengaruhi oleh faktor lain yang tdak diteliti.

2. Pengungkapan Sukarela tidak berpengaruh negatif terhadap Biaya Hutang. Penelitian ini tidak mendukung teori yang mengatakan pengungkapan sukarela berpengaruh negatif terhadap biaya hutang pada perusahaan dan tahun yang diteliti. Tetapi mendukung penelitian yang mengatakan bahwa pengungkapan sukarela tidak berpengaruh negatif terhadap biaya hutang.

\section{Saran}

1. Bagi peneliti selanjutnya yang tertarik untuk meneliti disarankan agar memperluas objek yang akan diteliti agar bisa di generalisasikan pada semua perusahaan yang terdaftar di Bursa Efek Indonesia dikarenakan penelitian ini hanya menggunanya 10 perusahaan dengan periode 3 tahun saja. Selain itu disarankan untuk peneliti selanjutnya tidak hanya meneliti variabel yang ada penelitian ini saja, tetapi juga diteliti faktor lain yang mempengaruhi biaya hutang.

2. Bagi Perusahaan agar dapat memperhatikan faktor yang dapat mengurangi biaya hutang yang akan didapatkan oleh perusahaan. Bagi para pemilik saham dari setiap perusahaan agar lebih meningkatkan pengawasan, hal ini sangat berguna sebagai bahan pertimbangan kreditor dalam memberikan biaya hutang kepada perusahaan dikarenakan perusahaan dengan kepemilikan institusional yang tinggi dianggap mengurangi risiko suatu perusahaan. perusahaan sebaiknya mempertimbangkan faktor dalam mengungkapkan suatu informasi, informasi yang berlebihan dan kurang berguna akan menambah biaya dalam pembuatan laporan tahunan juga tidak berpengaruh dalam mengurangi biaya bunga suatu perusahaan.

\section{Daftar Pustaka}

Aldamen, Husam et.al. 2010. Corporate Governance, Risk Assessment and Cost of Debt. Journal Bond University. Queensland. Australia.

Arief Budiman Anwar. 2010. Analisis Pengaruh Kualitas Pengungkapan Informasi Dan Rasio Keuangan Terhadap Harga Saham. Fakultas Ekonomi Universitas Indonesia. Jakarta. 
Arikunto, Suharsimi. (2006). ProsedurPenelitian: SuatuPendekatanPraktek. Jakarta: PT RinekaCipta

Botosan, Christine A. 1997. Disclosure Level and The Cost of Equity Capital. The Accounting Review Vol 72 No. 3. Washington University.

Brigham F. Eugene dan Houston, Joel. (2010). Dasar - Dasar Manajemen Keuangan : Assetials Of Financial Management. Jakarta: Penerbit Salemba Empat.

Eva Andriyah. 2009. Peranan Pengungkapan Informasi dalam Meningkatkan Praktik Good Corporate Governance. Skripsi. Bandung

Faisal. 2004. Analisis Agency Cost, Struktur Kepemilikan dan Mekanisme Corporate Governance. Simposium Nasional Akuntasi VII Denpasar. Bali.

Harahap, SofyanSyafri. (2007). TeoriAkuntansi. Jakarta: PT Raja GrafindoPersada

Healy, Paul M dan Krishna G. Palepu. 2001. Information Asymetry, Corporate Disclosure and The Capital Market. Journal of Accounting and Economics 31 (2001) 405-440. Boston.

Hendriksen, Eldon S dan Michael Van Breda. 2002. Teori Akunting Edisi Kelima Buku Dua. (Penerjemah: Herman Wibowo, Batam: Interaksara).

Indah Masri dan Dwi Martani. 2012. Pengaruh Tax Avoidance terhadap Cost of Debt. Jurnal Magister Akuntasi. Fakultas Ekonomi Universitas Indonesia.

Irma Agustin Leonita. 2012. Hubungan Antara Pelaksanaan Kerja Komite Audit dengan Tingkat Pengungkapan Modal Intelektual. Skripsi. Universitas Pendidikan Indonesia. Bandung.

Jetro Overseas Business Survey. Survey on the International Operation of Japanese Firms. http://www.jetro.go.jp/en/reports/survey/

Juniarti, dan Agnes Sentosa. 2009. Pengaruh Good Corporate Governance, Voluntary Disclosure Terhadap Biaya Hutang (Costs Of Debt). Jurnal Fakultas Ekonomi Universitas Kristen Petra.

Keiso, Donald et.al. 2008. Akuntansi Intermediate Edisi keduabelas jilid 1. Penrbit: Erlangga. Jakarta

Ketut Purnami. 2011. Pengaruh Kepemilikan Manajerial, Kepemilikan Institusional, Kebijakan Dividen Dan Leverage Pada Kos Keagenan (Agency Cost). Bali

Kuncoro, Mudrajat. 2003. Metode Riset untuk Bisnis dan Ekonomi. Jakarta: Erlangga

Lawrence J. Gitman and Chad J. Zutter. 2012. Principles of Managerial Finance $13^{\text {th }}$ edition. Pearson.

Lukman Syamsudin. 2007. ManajemenKeuangan Perusahaan. Jakarta: PT Raja GrafindoPersada

Madura. 2006. International Corporate Finance buku 2. Jakarta: Salemba Empat

Mukzi Garby Pamessa. 2012. Pengaruh Pengungkapan (Disclosure) Terhadap Informasi Asimetri Dan Pengarug Informasi Asimetri Terhadap Cost Of Equity Capital. Skripsi. Universitas Pendidikan Indonesia. Bandung

Norton Rose. 2011. Indonesia inward investment, an industry survey. http://www.nortonrosefulbright.com/files/indonesia-inward-investmentjune-2011-pdf-52492.pdf

Pittman, J., Fortin, S., (2004).Auditor choice and the cost of debt capital for newly public firms.Journal of Accounting and Economics 37, 113-136. 
R.Lanny Wulansari. 2004. Analisis Pengaruh Tingkat Pengungkapan Informasi Laporan Tahunan (Disclosure Level Annual Report) Terhadap Cost of Debt. Skripsi. Universitas Padjajaran. Bandung

Retno Kusumastuti dan Ida Bagus. 2011. Analysis of The Impact of Family Ownership on a Company's Cost of Debt. International Journal of Administrative Science and Organization. Jakarta

Sabrina. 2007. Pengaruh Luas Pengungkapan Sukarela dan Informasi Asymetri terhadap Cost of Equity Capital. Skripsi. Universitas Padjadjaran.

Scott, David F et.al . 2011. Basic Financial Management. $7^{\text {th }}$ Edition. Prentice Hall.

Scott, William R. 2003. Financial Accounting Theory $3^{\text {rd }}$. Toronto. Prentice Hall.

Sri Handaru Yuliati. 1997. Dasar dasar Manajemen Keuangan Internasional. Yogyakarta. Andi.

Sugiyono. (2011). Metode Penelitian Bisnis Kuantitatif Kualitati fdan R\&D. Bandung: Alfabeta

Tarjo, 2008. Pengaruh Konsentrasi Kepemilikan Institusional dan Leverage terhadap Management Laba dan Nilai Pemegang Saham serta Cost of Equity Capital. Simposium Nasional Akuntansi XI.

The World Bank. Mempercepat Laju Revitalisasi Pertumbuhan Sektor Manufaktur Indonesia. www.worldbank.org

Widya Sartika. 2012. Analisis Hubungan Penghindaran Pajak Terhadap Biaya Hutang dan Kepemilikan Institusional Sebagai Variabel Pemoderasi. Skripsi. Universitas Indonesia.

Wien Ika Permanasari. 2010. Pengaruh Kepemilikan Manajemen, Kepemilikan Institusional, Dan Corporate Social Responsibility Terhadap Nilai Perusahaan. Universitas Diponogoro. Semarang

Yeni Oktahidayanti. 2012. Pengaruh Struktur Kepemilikan Terhadap Return Saham Pada Perusahaan Subsektor Telekomunikasi Yang Terdaftar Di Bei. Skripsi. Universitas Pendidikan Indonesia. Bandung

Yulisa Rebecca. 2011. Pengaruh Corporate Governance Index, Kepemilikan Keluarga Dan Kepemilikan Institusional Terhadap Biaya Ekuitas Dan Biaya Utang: Studi Empiris Pada Perusahaan Manufaktur Yang Terdaftar Di Bei. Jurnal Universitas Indonesia. Jakarta

www.idx.co.id

www.neraca.co.id 